\title{
EVENT ORGANIZER SEBAGAI PELUANG WIRAUSAHA
}

\author{
Donny Perdana de Keizer
}

Jurusan Marketing Communication, Fakultas Komunikasi dan Multimedia, BINUS University

Jln. K.H. Syahdan No. 9, Kemanggisan, Palmerah, Jakarta Barat

\begin{abstract}
The article discusses business chance in event organizer that could be conducted by anybody. Less employment in this country is not balanced with the amount of college graduates every year, which is getting bigger. Government ability to create new jobs does not give a credible chance for new graduates to work. However, there are still chances in building new jobs by being entrepreneurs in event organizer sector. Event organizer service is a business that gives chances in effective employment for society; especially new college graduates so instead of competing to get jobs, they will create a self-employment and also for others. Beginning business in event organizer is not hard as we thought. In the article, it is attached several tips to begin event organizer business.
\end{abstract}

Keywords: event organizer, entrepreneur, tips

\begin{abstract}
ABSTRAK
Tulisan ini mengupas seputar peluang usaha di bidang event organizer atau penyelenggara Acara yang dapat dilakukan oleh siapa saja. Sempitnya lapangan kerja di tanah air tidak sebanding dengan meningkatnya jumlah lulusan perguruan tinggi setiap tahunnya. Kemampuan pemerintah menciptakan lapangan kerja di dalam negeri ternyata tidak mampu memberikan ruang bagi sarjana sarjana baru untuk bekerja. Masih terbuka peluang untuk membangun lahan baru di bidang wirausaha diantaranya sektor jasa pengelola acara atau event organizer. Jasa event organizer atau yang disebut juga EO ini merupakan sebuah bidang usaha yang memberikan peluang penciptaan lapangan kerja efektif bagi masyarakat khususnya bagi lulusan perguruan tinggi baru sehinga mereka tidak perlu bersaing untuk mencari pekerjaan namun membuka peluang untuk menciptakan lapangan kerja sendiri serta bagi orang lain. Memulai usaha di bidang EO ternyata tidaklah sesulit yang dibayangkan orang. Artikel ini juga membahas beberapa tips atau langkah langkah yang dapat dilakukan untuk memulai usaha EO.
\end{abstract}

Kata kunci: event organizer, wirausaha, saran 


\section{PENDAHULUAN}

Problem pengangguran terbuka di Indonesia masih belum bisa diatasi oleh pemerintah. Sepanjang 2009-2010, Kementerian Tenaga Kerja dan Transmigrasi (Kemenakertrans) hanya mampu menurunkan 1,5 persen dari total pengangguran tahun. Memasuki 2011 pengangguran terbuka sekarang ada pada angka 9,25 juta. Program baru pun disusun Kemenakertrans yakni bekerjasama dengan Kementerian Komunikasi dan Informatika (Kemenkominfo) dalam menyebar informasi lowongan kerja. Lembaga pendidikan yang seharusnya melahirkan tenaga terdidik malah sebaliknya ikut memberikan kontribusi meningkatnya jumlah pengangguran,khususnya pengangguran bergelar atau pengangguran terdidik.

Sempitnya lapangan kerja di tanah air yang tidak sebanding dengan meningkatnya jumlah lulusan perguruan tinggi setiap tahunnya menjadikan beban bagi pemerintah. Kemampuan pemerintah menciptakan lapangan kerja di dalam negeri ternyata tidak mampu memberikan ruang bagi sarjana sarjana baru untuk diserap di sektor kerja.

Bagi sebagian kalangan perguruan tinggi, hal ini menjadi peluang sekaligus tantangan untuk menghasilkan lulusan yang memiliki daya saing serta punya keahlian wirausaha. Masih terbuka peluang untuk membangun lahan baru di bidang wirausaha diantaranya sector jasa pengelola acara atau event organizer. Jasa event organizer atau yang disebut juga EO ini merupakan sebuah bidang usaha yang memberikan peluang penciptaan lapangan kerja efektif bagi masyarakat khususnya bagi lulusan perguruan tinggi baru sehinga mereka tidak perlu berjubel dengan lulusan perguruan tinggi lainnya untuk mencari pekerjaan namun membuka peluang untuk menciptakan lapangan kerja sendiri serta bagi orang lain.

\section{Event Organizer}

Menurut Wikipedia, Ovent Organizer atau EO adalah Penyelenggara Acara,atau Usaha dalam bidang jasa yang secara sah ditunjuk oleh clientnya, guna mengorganisasikan seluruh rangkaian acara, mulai dari perencanaan, persiapan, eksekusi hingga evaluasi, dalam rangka membantu mewujudkan tujuan yang diharapkan client dengan membuat acara.

Pada dasarnya EO merupakan orang orang yang bergerak dalam sebuah organisasi yang mengatur acara mulai dari perencanaan, pelaksanaan hingga purna acara. Di Indonesia, jasa EO sudah mulai berkembang namun dianggap belum mampu menjadi sebuah pilihan menarik bagi sebagian masyarakat kita untuk dijadikan sumber penghasilan utama. Hal ini yang menyebabkan masih sedikit EO di Indonesia yang mampu menguasai pasar besar. Disisi lain ini menjadi sebuah peluang bagi masyarakat untuk membuka usaha bidang jasa EO.

Ada beberapa jenis EO yang dikenal selama ini diantaranya adalah: (1) one stop service agency; (2) MICE atau meeting, incentive, convention and exhibition; (3) musik atau hiburan/promotor musik; (4) wedding planner atau wedding organizer; (5) ulang tahun; (6) personal organizer.

Event organizer one stop service agency merupakan sebuah EO berskala besar yang memainkan peran disegala jenis kegiatan baik berskala regional, nasional maupun Internasional. Aktivitas EO ini mulai dari kegiatan Below The line, Above the line hingga aktivitas lain yang memerlukan jasa EO.

EO MICE (meeting, incentive, convention dan exhibition) ini fokus pada kegiatan kegiatan yang menyangkut Meeting baik berskala nasional maupun Internasional. Selain itu kegiatan pameran juga menjadi fokus dari EO ini. 
Event organizer promoter musik ini khusus pada pertunjukan musik atau hiburan. Seperti EO jenis lain di atas, EO ini memerlukan spesialisasi keahlian khusus karena menangani kegiatan music bukanlah hal yang mudah. Beberapa EO jenis ini suda cukup eksis di Indonesia seperti Java Musikindo yang kerap menyelanggarakan pergelaran akbar musisi dalam maupun luar negeri.

Penyelenggara acara pernikahan merupakan sealah satu jenis EO yang banyak diminati oleh masyarakat. EO jenis ini focus pada semua hal yang berurusan dengan pernikahan mulai dari pre wedding hingga dokumentasi acara pernikahan. Mengelola Wedign organizer harus didukung juga oleh vendor vendor lain yang terkait dengan penyediaan fasilitas acara pernikahan. Salah satu kendala yang kerap dialami Wedding Organizer adalah ketersediaan sarana gedung untuk acara resepsi pernikahan.

Saat ini banyak pihak yang menunjuk EO untuk mengelola acara ulang tahun baik ulang tahun perusahaan atau ulang tahun perorangan. Semakin meningkatnya taraf hidup masyarakat Indonesia dewasa ini berujung pada semakin konsumtifnya pola hidup masyarakat sehingga penyelenggaraan pesta pribadi juga semakin menjadi sebuah kebutuhan.Banyak pihak yang kerap menyelenggarakan acara pribadi dalam skala besar yang memerlukan bantuan EO. Beberapa EO pun saat ini telah ditunjuk menjadi EO pribadi yang sewaktu waktu harus siap ketika diminta menjadi pengelola sebuah acara atau kegiatan.

\section{PEMBAHASAN}

\section{Memulai Wirausaha Bidang Event Organizer}

Bagi kalangan mahasiswa atau sarjana baru, peluang usaha di bidang EO ini selayaknya menjadi sebuah jenis pekerjaan yang menarik. Selain tidak memerlukan modal yang besar, bisnis di bidang jasa EO ini juga tidak memerlukan pendidikan khusus sehingga dapat dilakukan oleh siapa pun dengan latar belakang pendidikan formal yang berbeda beda.

Apabila dibandingkan dengan jenis usaha lain yang memerlukan modal awal besar, tempat usaha dan SDM maka bisnis jas EO hanya memerlukan modal Ide atau konsep dan jaringan teman yang luas. Memulai usaha EO bahkan tidak memerlukan tempat khusus seperti kantor atau ruang kerja khusus. Memulai usaha EO dapat dilakukan dengan bekerja dari rumah, menggunakan PC atau Laptop dan mengoptimalkan kemampuan komunikasi dan presentasi kepada calon klien.

Beberapa hal yang dapat dijadikan modal awal bagi setiap orang yang ingin memulai bisnis di bidang EO adalah: (1) mulailah dengan cinta; (2) ciptakan ide kreatif; (3) perbanyak teman atau relasi; (4) promosi dan kartu nama; dan (5) keberanian.

Pekerjaan apapun yang dilakukan seseorang tidak akan memberikan manfaat maksimal apabila dilakukan dengan setengah hati atau dengan keterpaksaan. Rasa cinta pada profesi menjadi kunci utama untuk memulai usaha bidang jasa EO ini. Aktivitas EO yang kerap berinteraksi dengan orang lain, memberikan pelayanan serta menghadapi konsumen yang banyak keinginannya kerap membuat seseorang merasakan tekanan kerja yang luar biasa. Namun apabila semua itu dilakukan dengan dilandari kecintaan pada profesi dan pekerjaan maka hal hal yang berpotensi menjadi kendala dalam pekerjaan itu akan dapat dihindari.

Menciptakan ide kreatif dapat dilakukan oleh siapa saja dan dengan metode apa saja. Setiap ide yang diciptakan daapt saja berupa ide baru yang lahir dari hasil oleh konsep pribadi ataupun ide yang dilahirkan dari pengembanganide yang telah ada sebelumnya. Melahirkan sebuah konsep acara yang menarik dan berbeda harus dilatih dan dibiasakan. 
Kunci sukses EO adalah terletak pada jaringan pertemanan yang luas. Sehingga semakin luas jaringan teman yang dimiliki akan semakin besar peluang Eo memperoleh pekerjaan atau proyek penyelenggaraan acara. Marketing menjadi ujung tombak bagi setiap jenis usaha, namun di bidang EO, self-marketing atau memasarkan diri sendiri menjadi sebuah keharusan.

Mencetak kartu nama adalah sebuah keharusan dalam memulai usaha bidang EO. Kartu nama adalah ujung tombak bagi setiap orang yang memulai usaha bidang ini. Sebaran kartu nama yang luas akan mengundang peluang yang luas pula bagi dikenalnya EO tersebut. Yang tidak dapat ditinggalkan juga adalah melakukan kegiatan promosi secara murah dan efektif. Banyak hal yang dapat dilakukan untuk melakukan promosi secara gratis dan tepat sasaran. Misalnya dengan menggunakan media internet, situs situs social yang banyak dikunjungi orang seperti Facebook dan twitter dinilai cukup efektif untuk menjadi media promosi EO. Memasang Logo Eo dan banner aktivktas EO lewat jejaring social di internet yang gratis, mejadi sebuah strategi promosi murah yang efektif.

Hal yang paling penting dari semua hal diatas adalah dibutuhkan keberanian untuk memulai dan mencoba usaha. Setiap orang yang memiliki konsep dan modal namun tidak memiliki keberanian memulai, hanya akan menjadi sebuah konsep semata. Namun bagi mereka yang berani memulai usaha dengan modal yang terbatas akan lebih memberikan peluang sukses di kemudian hari.

\section{Tahapan Praktis Memulai Usaha Event Organizer}

Modal dasar yang harus dimiliki seperti dipaparkan diatas adalah satu hal yang dapat dilakukan oleh siapa saja. Apabila hal hal diatas sudah dipenuhi, maka tahap selanjutnya adalah memulai usaha. Tidak perlu kuatir soal izin usaha karena apabila EO mendapatkan tawaran pekerjaan untuk menyelenggarakan sebuah acara dengan system lelang (pitching) pada perusahaan besar, maka legalitas lembaga EO dapat diantisipasi dengan system sub EO. Sub EO adalah kondisi dimana Eo akan memasukkan penawaran proposal dengan menggunakan bendera perusahaan lain yang begerak dibidang jasa yang sama namun seluruh akvititas produksi acaranya dilakukan sendiri. Keuntungan dari proyek yang dikerjakan tersebut yang akan dibagi antara EO yang di sub kerja kan dengan EO yang dipinjam benderanya.

Bagi kalangan mahasiswa atau sarjana baru yang saat ini masih harus berjubel dengan lulusan perguruan tinggi lain untuk mencari pekerjaan, mungkin perlu mencoba jenis usaha ini dengan saransaran, yaitu: (1) kumpulkan teman yang satu visi; (2) bentuk organisasi; (3) buat akun di situs sosial; (4) ikuti banyak acara; dan (5) melaksanakan acara sendiri atau teman.

Mengerjakan usaha EO memang dapat dilakukan sendiri. Namun alangkah baiknya apabila pekerjaan ini dilakukan oleh team. Team tidak harus banyak orang namun cukup dengan team yang beranggotakan 3 atau 4 orang saja. Kumpulkan rekan yang sama sama interest di bidang EO untuk sama sama memulai usaha.

Organisasi ini yang menjadi acuan dalam melakukan pembagian tugas dalam EO. Harus ada yang menjadipenanggung jawab atau pimpinan serta siapa yang ditugaskan sebagai staf yang melaksanakan bidang teknis dilapangan. Tidak menjai soal badan hukum yang dianut oleh OE namun yang penting adalah melakukan pembagian tugas yang jelas antara orang orang yang terlibat didalamnya sehingga setiap orang harus tahu hak dan kewajibannya. Intinya siapa-melakukan-apa harus sudah dijelaskan diawal memulai usaha.

Facebook dan Twitter saat ini dapat diandalkan sebagai media sosial yang banyak dikunjungi orang. Melakukan promosi lewat situs jejaring sosial ini merupakan sebuah strategi promosi yang murah dan efisien. EO dapat membuka akun khusus yang menampilkan informasi lengkap seputar jasa yang ditawarkan oleh EO. 
Perluas wawasan pengurus EO dengan banyak mengikuti acara atau kegiatan yang diselenggarakan oleh EO lain. Hal ini akan memberikan kesempatan bagi Eo untuk melahirkan ide atau konsep penyelenggaraan acara baru. selain itu kesempatan menghadiri acara lain juga memberikan kesempatan melakukan promosi langsung kepada vendor atau calon mitra kerja yang terlibat di acara tersebut. Disinilah kekuatan menyebarkan kartunama sangat berpengaruh.

Sebagai batu loncatan sekaligus bahan untuk melatih EO menyelenggarakan acara, dapat dilakukan dengan membuat acara sendiri atau menawarkan diri mengelola acara seorang rekan secara gratis. Hal ini dilakukan sebagai cara mempertajam kemampuan EO menyelenggarakan acara sekaligus sebagai sarana promosi bagi masyarakat. Apabila acara yang diselenggarakan tersebut sukses maka EO secara tidak langsung akan memperoleh kesempatan melakukan promosi gratis sekaligus sebagai bukti eksistensi EO dalam menjalankan usahanya.

\section{PENUTUP}

Tidak ada pohon yang tumbuh dalam waktu semalam. Setiap usaha yang sukses memerlukan keberanian untuk memulai, kesabaran menjalankannya serta banyak belajar untuk memperbaiki diri. Event organizer dapat dijadikan sebagai sebuah jenis usaha menarik yang dapat dijadikan sebagai sumber penghasilan utama masyarakat saat ini. Dengan modal awal yang sangat kecil, EO dapat menghasilkan profit yang besar bagi pengelolanya sehingga jenis usaha ini bukan tidak mungkin akan menjadi jenis usaha yang akan dilirik oleh banyak pihak khususnya bagi mahasiswa atau sarjana baru. Beban negara yang setiap tahun harus menanggung lahirnya jutaan pengangguran baru tentu akan semakin berkurang dengan terciptanya lapangan kerja melalui jasa Event Organizer ini.

\section{DAFTAR PUSTAKA}

Beatrix, S. (2006). I Love Organize. Panduan Praktis Mengelola Event, Jakarta: Gramedia Pustaka Utama

Grey, A. M., \& Reid, K. S. (2006). Event Sponsorship. Jakarta:PPM 